\title{
Water-retaining polymer and seedling type when planting irrigated coffee $^{1}$
}

\author{
Polímero hidro retentor e tipos de mudas na implantação de cafeeiros irrigados
}

\author{
Antonio Jackson Jesus Souza ${ }^{2 *}$, Rubens José Guimarães ${ }^{3}$, Anderson William Dominghetti ${ }^{3}$, Myriane Stella \\ Scalco $^{3}$ and Tiago Teruel Rezende ${ }^{3}$
}

\begin{abstract}
The aim of this work was to evaluate the use of a water-retaining polymer on the initial growth of coffee plants for different levels of irrigation and types of seedling. The experiment was set up in pots with a clayey soil, in a greenhouse of the Sector for Coffee Production of the Federal University of Lavras, Brazil. The experiment was arranged in a randomised block design into sub-lots with three replications, giving a total of 48 experimental units. Four levels of irrigation $(25 \%, 50 \%$, $75 \%$ and $100 \%$ of the available water) were randomly assigned to the lots; the type of seedling (grown in bags or tubes) were randomly assigned to the sub-lots, and the use or not of the water-retaining polymer randomly assigned to the sub-sub-lots. In the treatments with water-retaining polymer, a dilution of $1.5 \mathrm{Kg}$ of polymer to 400 litres of water was used at a dose of 1.5 litres of solution per plant. The following were evaluated at intervals of 60 days during the experiment (360 days from planting): stem diameter, plant height, leaf area, number of leaves and number of plagiotropic branches on the coffee plants. Hydrated water-retaining polymer favoured the growth of coffee plants under an irrigated system. Irrigation resulted in greater plant growth, with the seedlings grown in bags showing more growth than those grown in tubes.
\end{abstract}

Key words: Seedling containers. Implementation. Coffea arabica L.. Hydrogel.

\begin{abstract}
RESUMO - Objetivou-se avaliar o uso do polímero hidro retentor no crescimento inicial de cafeeiros em diferentes níveis de irrigação e tipos de mudas. O experimento foi instalado em vasos com solo argiloso, em casa de vegetação do Setor de Cafeicultura, Universidade Federal de Lavras. O experimento foi conduzido em delineamento de blocos ao acaso com parcelas sub-subdivididas e três repetições, totalizando 48 unidades experimentais. Quatro níveis de irrigação $(25 \% ; 50 \% ; 75 \%$ e $100 \%$ de água disponível) foram aleatorizados às parcelas; os tipos de mudas (formadas em saquinho e tubete) foram aleatorizadas às sub-parcelas; e a ausência ou presença do polímero hidro retentor foram aleatorizados nas sub-subparcelas. Nos tratamentos com uso do polímero hidro retentor utilizou-se a diluição de 1,5 kg de polímero em 400 litros d'água, para utilização da dose de 1,5 litros da solução por planta. Em intervalos de 60 dias durante a condução do experimento (360 dias a partir da implantação), avaliou-se o diâmetro de caule, altura de planta, área foliar, número de folhas e número de ramos plagiotrópicos dos cafeeiros. O polímero hidro retentor hidratado beneficiou o crescimento do cafeeiro em sistema irrigado. A irrigação promoveu maior crescimento das plantas, sendo que as mudas formadas em saquinhos apresentam maior crescimento que mudas em tubetes.
\end{abstract}

Palavras-chave: Recipientes de mudas. implantação. Coffea arabica L.. Hidrogel.

\footnotetext{
DOI: $10.5935 / 1806-6690.20160039$

*Autor para correspondência

${ }^{1}$ Recebido para publicação em 27/03/2014; aprovado em 27/10/2015

Parte da Tese de Doutorado do primeiro autor, apresentada ao Programa de Pós-Graduação em Agronomia/Fitotecnia da Universidade Federal Lavras/UFLA

${ }^{2}$ Departamento de Fitotecnia, Universidade Federal de Lavras/UFLA, Av. Doutor Sylvio Menicucci, 1001 Kennedy, Lavras-MG, Brasil, 37.200-000, jacksonagro@gmail.com

${ }^{3}$ Universidade Federal de Lavras/UFLA, rubensjg@dag.ufla.br, msscalco@deg.ufla.br, andersonwd10@yahoo.com.br, tiago.teruel@yahoo. com.br
} 


\section{INTRODUCTION}

Coffee is one of the main products of international agribusiness; generating a large number of direct and indirect jobs, and distributing income throughout the production chain, especially to the families of coffee farmers and rural workers. Brazil is the world's largest coffee producer, and Minas Gerais is the state with the largest production, producing 26.64 million sacks of coffee in 2014, corresponding to $55.12 \%$ of all Brazilian production (CONAB, 2014).

Despite the importance of coffee to the country, farmers face difficulties in carrying out their activities, one of the main difficulties being implementation of the coffee crop.

Irrigation supplies water, enabling the full growth and development of the coffee plants. However, in regions with low water availability, or even in regions with satisfactory levels of precipitation, water deficits are seen throughout the year due to poor rainfall distribution. In 2014, in the south of Minas Gerais, the mean historical rainfall for January was $320 \mathrm{~mm}$, but only $61 \mathrm{~mm}$ occurred during the period (CARVALHO; ADÃO, 2014).

An alternative way to help compensate for the poor distribution of rainfall or even optimize the availability of water in drier regions, may be the use of water-retaining polymers, which have the capacity to retain water during rainfall or irrigation, and make it available in times of water deficit. Polyacrylamide polymer (a hydroretaining polymer) when hydrated, displays gelatinous characteristics, and is able to release water over time, reducing irregularities in the availability of water to plants (ZONTA et al., 2009).

The best way to evaluate the effects of soil type, type of seedling container, and irrigation system on coffee plants, is by quantifying vegetative growth. Carvalho et al. (2010) noted a high positive correlation of vegetative characteristics with the initial productivity of coffee plants in different coffee-producing regions.

There is insufficient information in the literature concerning the effects of water-retaining polymer on different types of seedlings when planting coffee plants, especially regarding the use of the polymer in irrigated systems. The aim was to evaluate the effects of the availability of water for irrigation, the use of waterretaining polymer and the type of seedling (bag and tubes), when planting coffee.

\section{MATERIAL AND METHODS}

The experiment was conducted at the Sector for Coffee Production of the Federal University of Lavras
(UFLA), in the State of Minas Gerais, Brazil. Located at $21^{\circ} 15^{\prime} \mathrm{S}$ and $45^{\circ} 00^{\prime} \mathrm{W}$, at an average altitude of $918 \mathrm{~m}$ (DANTAS; CARVALHO; FERREIRA, 2007).

The experiment was carried out in a randomised block design. For operational reasons, sub-divided lots were used with three replications. Irrigation levels were randomised across the lots $(25 \% ; 50 \% ; 75 \%$ and $100 \%$ of the available water) the seedlings, grown in two types of container (bags and tubes), were randomised across the sub-lots, and the factor, water-retaining polymer (with and without), was randomised across the sub-sub-lots, giving a total of 48 experimental units.

Coffee seedlings were produced from seeds of the Acaia Cerrado MG-1474 cultivar at the site of the experiment. The seedlings grown in bags (B) $(11 \times 22 \mathrm{~cm})$ used a standard substrate (300 L cattle manure, $700 \mathrm{~L}$ soil and $5 \mathrm{~kg}$ single superphosphate), and those in tubes (T) $(120 \mathrm{~mL})$, a commercial substrate (composted pine bark and vermiculite) with the addition of $1 \mathrm{~g}$ of slow-release fertiliser (15-10-10 NPK) per tube. After production, the seedlings were placed into pots to simulate planting in the field. The pots were of 20 litres for better control of irrigation. These were placed on benches $0.8 \mathrm{~m}$ above the ground at a spacing of $0.70 \times 0.60 \mathrm{~m}$. The soil used was a dystroferric Red Latosol (DfRL) (Table 1) as per the Brazilian system of soil classification (SANTOS, 2013).

Soil correction was carried out by raising the base saturation to $60 \%$ using dolomitic limestone with a PRNT of $87 \%$ mixed with the moist soil, which was piled up and covered with canvas for 26 days to react. Fertiliser application at planting and throughout the experiment, was performed following the recommendations of Faquin, Vale and Furtini Neto (2008).

For the treatments with water-retaining polymer, the solution was prepared in the ratio of $1.5 \mathrm{~kg}$ of the polymer to 400 litres of water, applying 1.5 litres of the solution to the planting hole when planting the seedlings, following the recommendations of Pieve et al. (2013).

For the pots with no polymer (the reference for setting irrigation levels) undisturbed soil samples were collected using a Uhland cylinder to characterise the water retention curve of the soil. The moisture $\left(\mathrm{g} \mathrm{g}^{-1}\right)$, pressure or matric potential $(\mathrm{kPa})$, and the soil-water characteristic curve were verified to create a spreadsheet to determine the amount of water to be applied in each irrigation treatment. From the soil-water characteristic curve, the volume of water needed to restore field capacity was determined (treatment of 100\%), together with the reductions in this volume for establishing the other irrigation treatments $(75 \%, 50 \%$ and $25 \%)$. Irrigation was carried out on Mondays and Thursdays by the manual application of 
Table 1 - Physical and chemical analysis of the soil used in the experiment

\begin{tabular}{|c|c|c|c|c|c|c|c|c|c|c|c|c|}
\hline SOIL & Clay & $\mathrm{pH}$ & $\mathrm{P}$ & $\mathrm{K}$ & $\mathrm{Na}$ & $\mathrm{Ca}$ & $\mathrm{Mg}$ & $\mathrm{Al}$ & $\mathrm{H}+\mathrm{Al}$ & SB & $(\mathrm{t})$ & (T) \\
\hline Class & dag $\mathrm{kg}^{-1}$ & $\left(\mathrm{H}_{2} \mathrm{O}\right)$ & \multicolumn{3}{|c|}{-----------mg dm ${ }^{-3}---------$} & ---- & $-\mathrm{cmc}$ & $m^{-3}-$ & ------- & \multicolumn{3}{|c|}{--------cmol $\mathrm{dm}^{-3}$-------- } \\
\hline DfRL & 65 & 6 & 2.6 & 41 & - & 4.1 & 0.4 & 0 & 3.2 & 4.6 & 4.6 & 7.8 \\
\hline SOIL & $\overline{\mathrm{V}}$ & $\bar{M}$ & $\mathrm{MO}$ & \multicolumn{2}{|c|}{ Prem } & $\mathrm{Zn}$ & $\mathrm{Fe}$ & $\mathrm{Mn}$ & $\overline{\mathrm{Cu}}$ & \multicolumn{2}{|c|}{$\mathrm{B}$} & $S$ \\
\hline Class & \multicolumn{2}{|c|}{-------\%------ } & dag $\mathrm{kg}^{-1}$ & \multicolumn{2}{|c|}{-----mg L $\mathrm{m}^{-1}-----$} & ---- & - & - & $\mathrm{mg} \mathrm{dm}$ & - & & --- \\
\hline DfRL & 58.6 & 0 & 3.6 & 11.0 & & 2.5 & & 19.1 & 3.4 & 0.8 & 0.2 & 14.9 \\
\hline
\end{tabular}

the corresponding volume of water for each treatment, measured using a graduated cylinder.

Evaluations were made every 60 days for a total period of 360 days, giving a total of six periods of evaluation. The following growth variables were determined in the evaluations: stem diameter (SD) in $\mathrm{mm}$, using digital calipers $(\mathrm{mm})$ when collecting the plant; plant height $(\mathrm{PH})$ in $\mathrm{cm}$, from the base to the apical meristem, using a graduated rule; leaf area (AF) in $\mathrm{cm}^{2}$, measured using a rule graduated in centimetres (multiplying the greatest length by the greatest width of one leaf from each pair, and then multiplying by the constant 0.667 , multiplying by two, and finally summing the leaf area obtained for each pair, to get the total leaf area of the plant); and the number of leaves (NL), determined by counting true leaves greater than $2.5 \mathrm{~cm}$ in length. Finally, the number of plagiotropic branches (NPB) was counted.

The collected data were tabulated, and tests for normality and homogeneity were performed. With the help of the SISVAR ${ }^{\circledR}$ statistical analysis software (FERREIRA, 2011), analysis of variance was carried out. The interactions for the water levels in each type of seedling, with or without the use of water-retaining polymer, were broken down when significant by regression analysis.

\section{RESULTS AND DISCUSSION}

In the first evaluation at 60 days, the effect from the interaction of irrigation level with type of seedling (I x S) was seen on stem diameter (SD) and plant height (PH). With the breakdown of the interaction, a significant effect from the bag container (B) could be seen on the SD and PH (Figure 1a and 1b). For SD an increasing linear trend was noted for increases in irrigation levels. Water supplied at $100 \%$ (100\% of the available water) favoured a larger SD (Figure 1a). Determination of stem diameter is important in biometric evaluations, as Almeida et al. (2005) observed that the stem diameter determines a higher survival rate for coffee seedlings in the field.

A quadratic trend was found for $\mathrm{PH}$, with a peak at $90 \%$ of the irrigation level (Figure 1b). Greater plant heights were observed by Azevedo et al. (2002), when evaluating the levels of polymer and frequency of irrigation on the growth of coffee seedlings. Those authors noted that in the absence of polymer, the plant height was higher for a lower frequency of irrigation, i.e. with a greater supply of water per application, confirming the findings of the present work.

For leaf area (LA), only the effects of irrigation (I) were seen (Figure 1c). An irrigation level of $82 \%$ of the available water gave a maximum leaf area of $491 \mathrm{~cm}^{2}$. At the irrigation level of $25 \%$, it was found that the plants displayed $35.6 \%$ less development than that observed at the irrigation level of $82 \%$. In general, one of the first responses of plants to water deficit is a reduction in leaf area, being either a result of leaf abscission, the production of smaller leaves, or even a reduction in the emission of new leaves (ATKINSON et al., 1999).

With the number of leaves (NL), there was an effect from the type of seedling (S) only. Seedlings in bags (B) displayed a higher number of leaves (14) than those from tubes (T) (13) (Table 3), this difference is significant, being $7.14 \%$ greater, and reflecting in a larger area for the production of photoassimilates. According to Livramento (2010), the adequate supply of carbohydrates for the production of photoassimilates is directly influenced by the number of leaves.

For the characteristic, SD, an effect was seen from the interaction between irrigation and water-retaining polymer ( $\mathrm{I}$ x G), where, in the breakdown at 120 days after planting, it was found that an increase in irrigation levels had a linear trend on the growth of the SD (Figure 2a). Alves et al. (2000) claim that coffee plants have more developed shoots with larger stem diameters, as irrigation tends to supply what is lost by evapotranspiration. At the largest supply of water to the coffee plant (levels 
Figure 1 - Stem diameter $(\mathrm{mm})(\mathrm{a})$, plant height $(\mathrm{cm})(\mathrm{b})$ and leaf area $\left(\mathrm{cm}^{2}\right)(\mathrm{c})$ at 60 days after planting, in the Acaiá Cerrado MG-1474 coffee cultivar, for level of irrigation
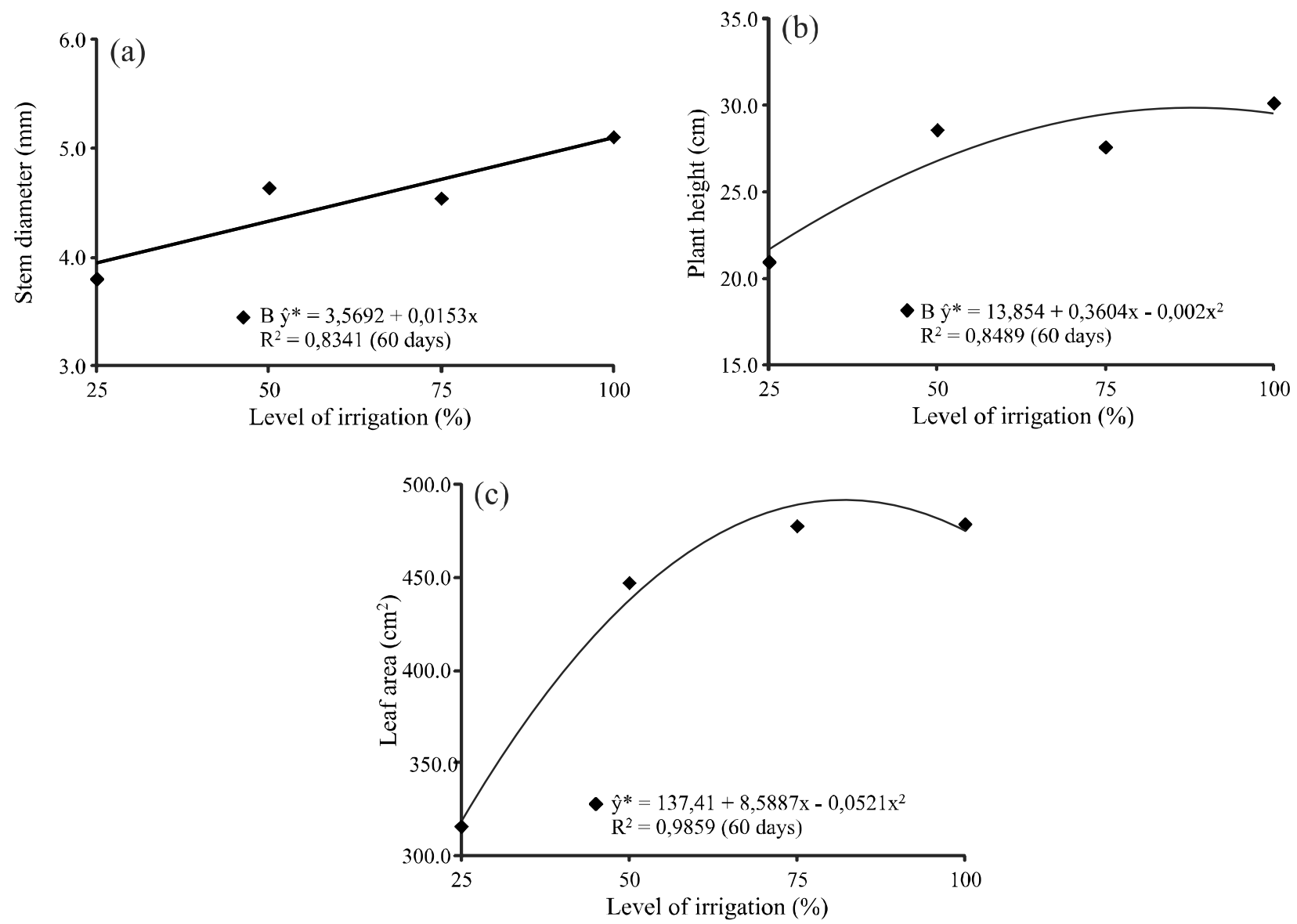

${ }^{*}$ Significant difference by F-test at $5 \%$ probability within each period

of $75 \%$ and $100 \%$ ), the difference in SD is small, with or without use of the polymer (Figure 2a). Pieve et al. (2013), evaluating stem diameter in coffee at 111 days after planting in the field, found no difference for the presence or absence of polymer during the rainy season, possibly due to the sufficient supply of water.

After 120 days, under conditions of water deficit ( $25 \%$ and $50 \%$ of the irrigation level), seedlings grown in the presence of the water-retaining polymer had a visually larger stem diameter when compared to those not grown with the product. Tohidi-Moghadam et al. (2009), studying the response of rapeseed to water stress and the application of water-retaining polymer, concluded that its use increased the performance of agronomic and physiological characteristics, attributing the supply of water that favoured photosynthesis and chlorophyll content to the application of the gel.

In the evaluation at 120 days after the beginning of the experiment, an effect was noted on LA and NL from the interaction Ix S. As the interaction was broken down, an effect from irrigation level was seen on LA (Figure 2b) and NL (Figure 2c), which were greater with the increase in irrigation levels for seedlings from the bags. In the case of the bags, there is possibly greater storage of the applied water, which may have led to an increase in the growth of leaves. For Atkinson et al. (1999), an increase in moisture provides an increase in leaf area and number of leaves.

At 120 days after planting, the $\mathrm{PH}$ was influenced with a linear trend, but only by the effects of irrigation. The greatest $\mathrm{PH}$ was found at a level of $100 \%$ (Figure 2d), the level of $25 \%$ resulting in an average increase of 22.44 $\mathrm{cm}$ in plant height. Increased plant growth was also found by Alves et al. (2000) when planting irrigated coffee.

For the number of plagiotropic branches (NPB) at 120 days, it was found that the coffee plants grown in bags had three branches and the seedlings grown in tubes had only two (Table 3). The faster growth of the seedlings in bags at 120 days was also seen by Vallone et al. (2010) 
Figure 2 - Stem diameter (mm) (a), leaf area $\left(\mathrm{cm}^{2}\right)(\mathrm{b})$, number of leaves (c) and plant height (cm) (d) at 120 days after planting, in the coffee cultivar Acaiá Cerrado MG -1474, for level of irrigation
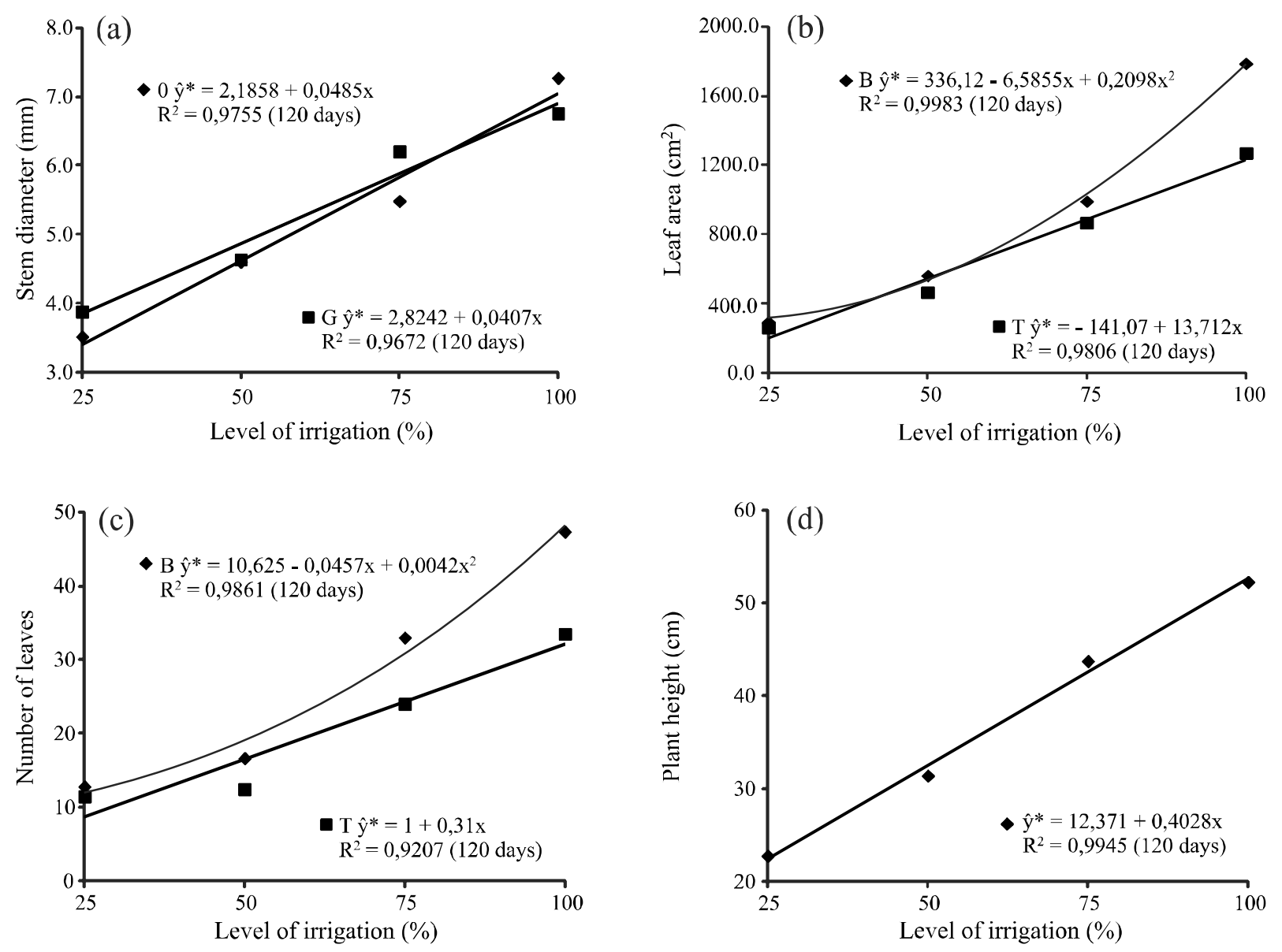

"Significant difference by F-test at 5\% probability within each period

when evaluating the effect of container and substrate on the production of coffee seedlings.

With the evaluations carried out at 180 and 240 days after planting the coffee, a similar effect was found from the interaction I x B x G on PH (Figure 3a and 5a). Breaking down the this interaction for AP, a similar linear trend was found for height in the plants from bags and tubes, with or without polymer, since in the triple interaction the effect of irrigation on plant height was decisive. At 180 days after planting, each $25 \%$ increase in irrigation level caused a variation of 19.09, 27.70, 20.75 and $20.60 \mathrm{~cm}$ for the treatments, bag with no polymer (B0), bag with polymer (BG), tube with no polymer (T0) and tube with polymer (TG) respectively (Figure 3a). At 240 days after planting, each 25\% increase in irrigation level resulted in a variation of 19.70, 30.14, 20.81 and 22.15 in $\mathrm{PH}$ for the treatments S0, SG, T0 and TG respectively (Figure 5a). This result can be attributed to the increased water retention of those treatments using both polymer and container. The water-retaining polymer acts as a soil conditioner, in part resembling the presence of organic matter or clay in the soil. Oliveira et al. (2004), when working with sandy clay loam and clay soils, found an increase in water retention up to a matric potential of $-1.0 \mathrm{MPa}$.

When breaking down the interaction between irrigation and type of seedling ( $\mathrm{I} \times \mathrm{S}$ ) for NL at 180 days, a significant effect was observed from irrigation. With the increase in irrigation levels a positive linear trend was seen, i.e. there was a greater number of leaves (Figure 3b). The result for NL at 180 days was similar to that observed at 120 days. In this case the difference between the seedling containers reached 18 leaves at $100 \%$ of the irrigation level.

At 240 days, it was found that seedlings grown in bags had a greater number of leaves (69) in relation to those grown in tubes (62) (Table 3). This greater number of leaves will possibly favour greater plant 
development in later stages, as noted by Santana, Oliveira and Quadros (2004) who, when evaluating the initial growth of coffee plants, found a difference between irrigation systems from 226 days after planting.

The SD at 180 and 240 days showed similar behaviour for irrigation (Figure $4 \mathrm{a}$ and $5 \mathrm{~b}$ ). A water deficit of $25 \%$ compromised development of the SD by 3.62 and $3.72 \mathrm{~mm}$, at 180 and 240 days respectively. These results were less than those obtained by Scalco et al. (2002) for the same period, when evaluating planting densities on initial plant growth in coffee plants. The level of $100 \%$ favoured an increase in the SD, which after 180 and 240 days was 7.01 and $9.87 \mathrm{~mm}$ respectively. Similar results were found by Santana, Oliveira and Quadros (2004) for irrigated coffee plants at 181 days after planting, with a stem diameter of $7.7 \mathrm{~mm}$.

Figure 3 - Plant height (cm) (a) and number of leaves (b) at 180 days after planting, in the coffee cultivar Acaiá Cerrado MG -1474, for level of irrigation
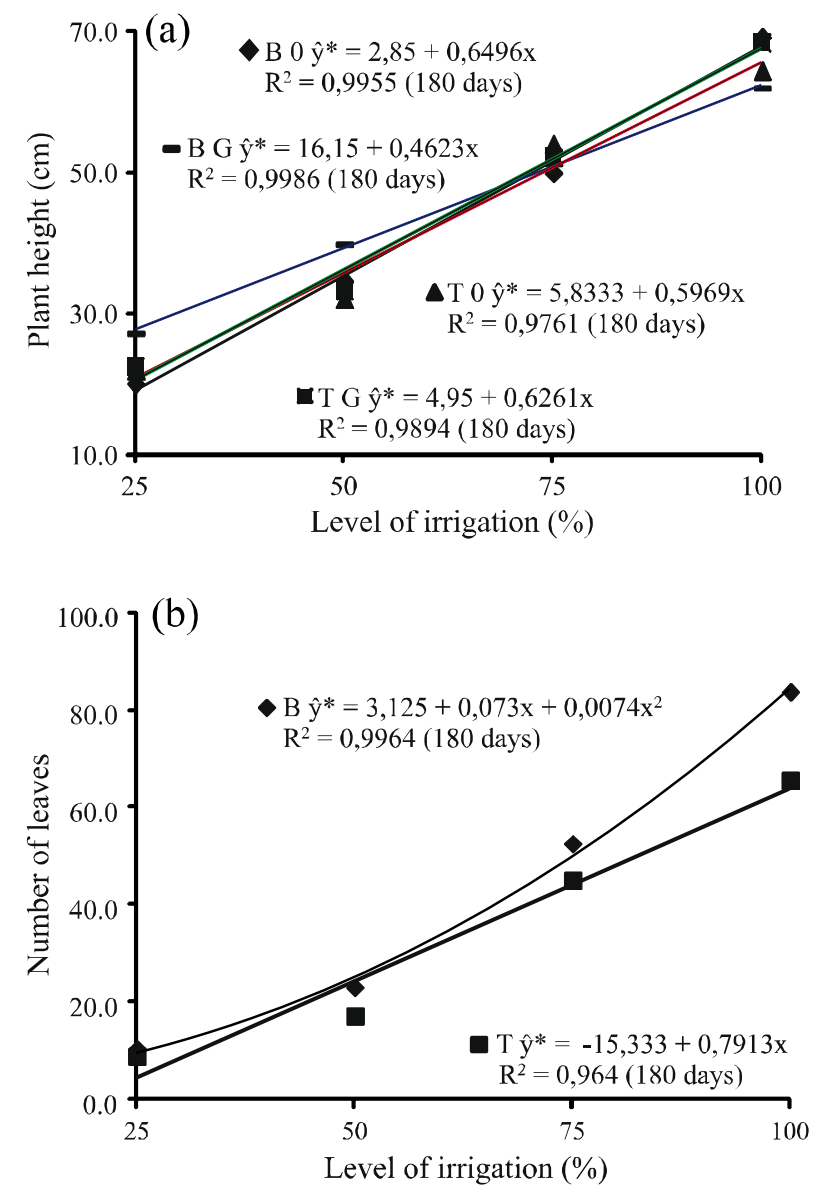

${ }^{*}$ Significant difference by F-test at $5 \%$ probability within each period
The LA of the plants at 180 and 240 days displays similar behaviour for irrigation (I). A water deficit of $25 \%$ compromised the leaf area, which was only 276.5 and $260.5 \mathrm{~cm}^{2}$, compared to the level of $100 \%$, when it was 1527.4 and $2475.4 \mathrm{~cm}^{2}$ at 180 and 240 days respectively (Figures $4 \mathrm{~b}$ and $5 \mathrm{c}$ ). This increase in LA can be explained by the greater availability of water, the phenomenon being due to the relationship between the size reached by the leaves and the moisture in the soil (FAVARIN et al., 2002). Martins et al. (2006), in a study into the initial growth of conilon coffee under different levels of irrigation, point out that in treatments where less water was available, plant growth was impaired; the proper management of irrigation water is therefore necessary for good plant growth.

At 300 days after planting, there was an effect from the interaction I x B on NL. Breaking down the interaction,

Figure 4 - Stem diameter (mm) (a) and leaf area $\left(\mathrm{cm}^{2}\right)(\mathrm{b})$ at 180 days after planting, in the coffee cultivar Acaiá Cerrado MG -1474, for level of irrigation
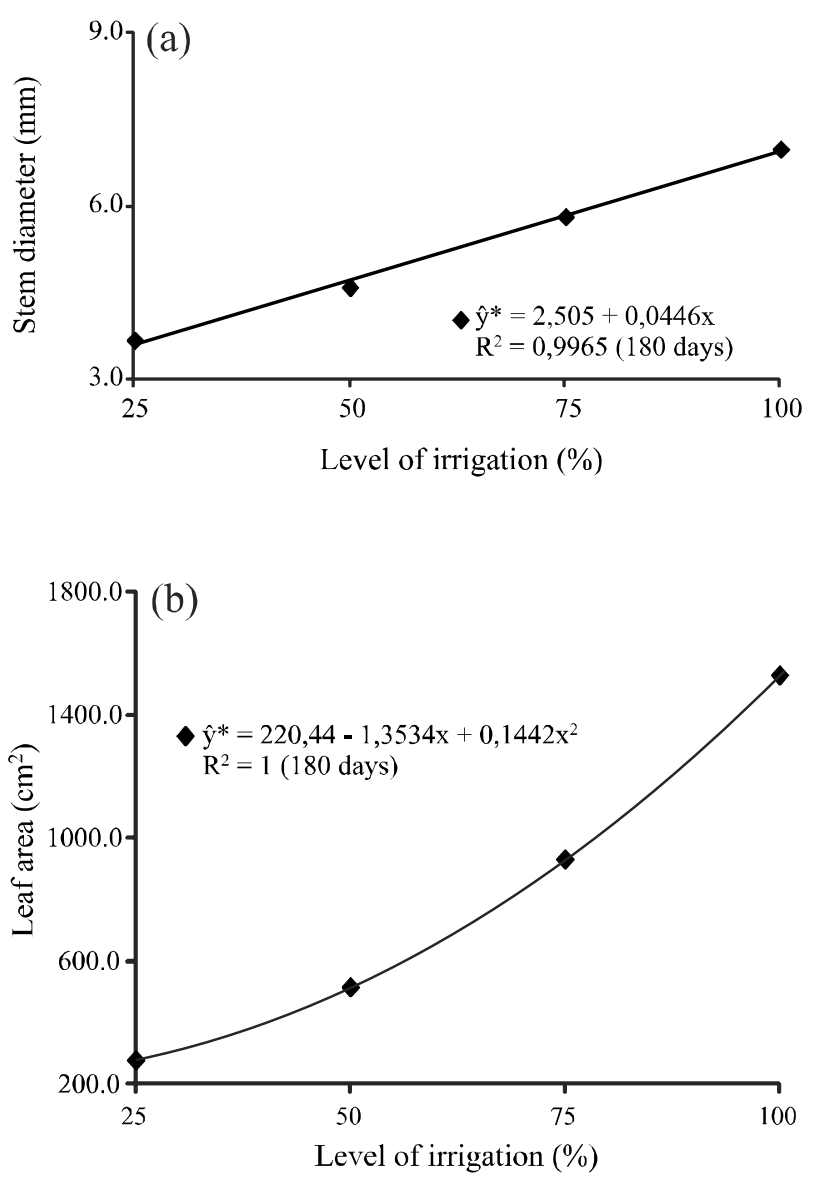

*Significant difference by F-test at $5 \%$ probability within each period 
Figure 5 - Plant height $(\mathrm{cm})(\mathrm{a})$, stem diameter $(\mathrm{mm})(\mathrm{b})$ and leaf area $\left(\mathrm{cm}^{2}\right)(\mathrm{c})$ at 240 days after planting, for the interactions (I x S) and (I x G), in the coffee cultivar Acaiá Cerrado MG -1474, for level of irrigation
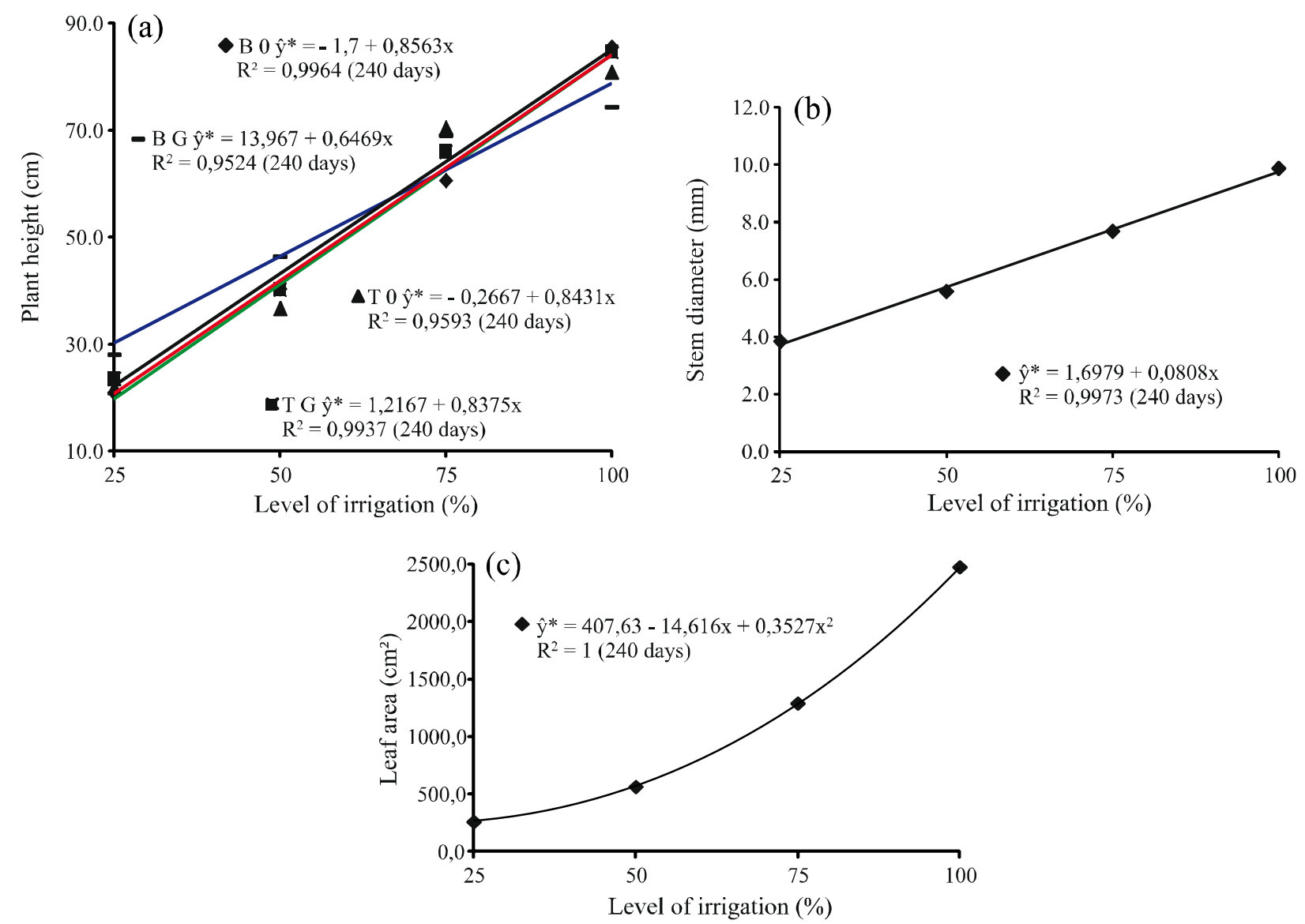

${ }^{*}$ Significant difference by F-test at $5 \%$ probability within each period

a significant effect from the irrigation level was found in both types of seedling in the regression analysis, showing a positive linear trend for NL with the increase in irrigation levels. Irrigation, as seen in previous periods, clearly interferes with the number of leaves. For each $25 \%$ increase in the applied irrigation level, an increase of 10 and 8 leaves was seen in the seedlings from the bags and tubes respectively (Figure 6a).

At 300 days after planting, stem diameter in the coffee plants was only influenced by the effect of irrigation (Figure 6b). With increases in the applied levels of irrigation, there were greater increases in SD. By comparing the maximum level of irrigation with irrigation carried out at half the level, there was a difference of 8.45 $\mathrm{mm}$ (Figure 6b). The increase in SD, was $46.6 \%$ for an increase of $50 \%$ in the level of irrigation; similar behaviour was observed in previous periods.

For leaf area at 300 days, an effect was seen from the water-retaining polymer $(\mathrm{G})$; seedlings that received an application of the product displayed a larger leaf area, i.e. $2913.9 \mathrm{~cm}^{2}$, while without the water-retaining polymer the leaf area was $2557.4 \mathrm{~cm}^{2}$ (Table 2). This increase in LA may promote greater plant development at later stages, as in the work by Azevedo et al. (2002), who noted satisfactory effects from the polymer on coffee plants, also with increases in leaf area.

By analysing LA at 300 days, greater development was also seen at $100 \%$ of the irrigation level (Figure 6c). Alves et al. (2000), evaluating irrigated and nonirrigated coffee, found that plants under water deficit grow less in height than plants under irrigation, as water stress can affect the metabolic processes of plant growth.

Analysing the number of plagiotropic branches (NPB) at 300 days, an increasing quadratic trend was also seen for this characteristic, for up to $100 \%$ of the irrigation level (Figure 6d), where it peaked. For Vale, Carvalho and Paiva (2006), the use of irrigation also increased the NPB 
Figure 6 - Number of leaves (a), stem diameter (mm) (b), plant height (cm) (c) and number of plagiotropic branches (d), at 300 days after planting, in the coffee cultivar Acaiá Cerrado MG -1474, for level of irrigation
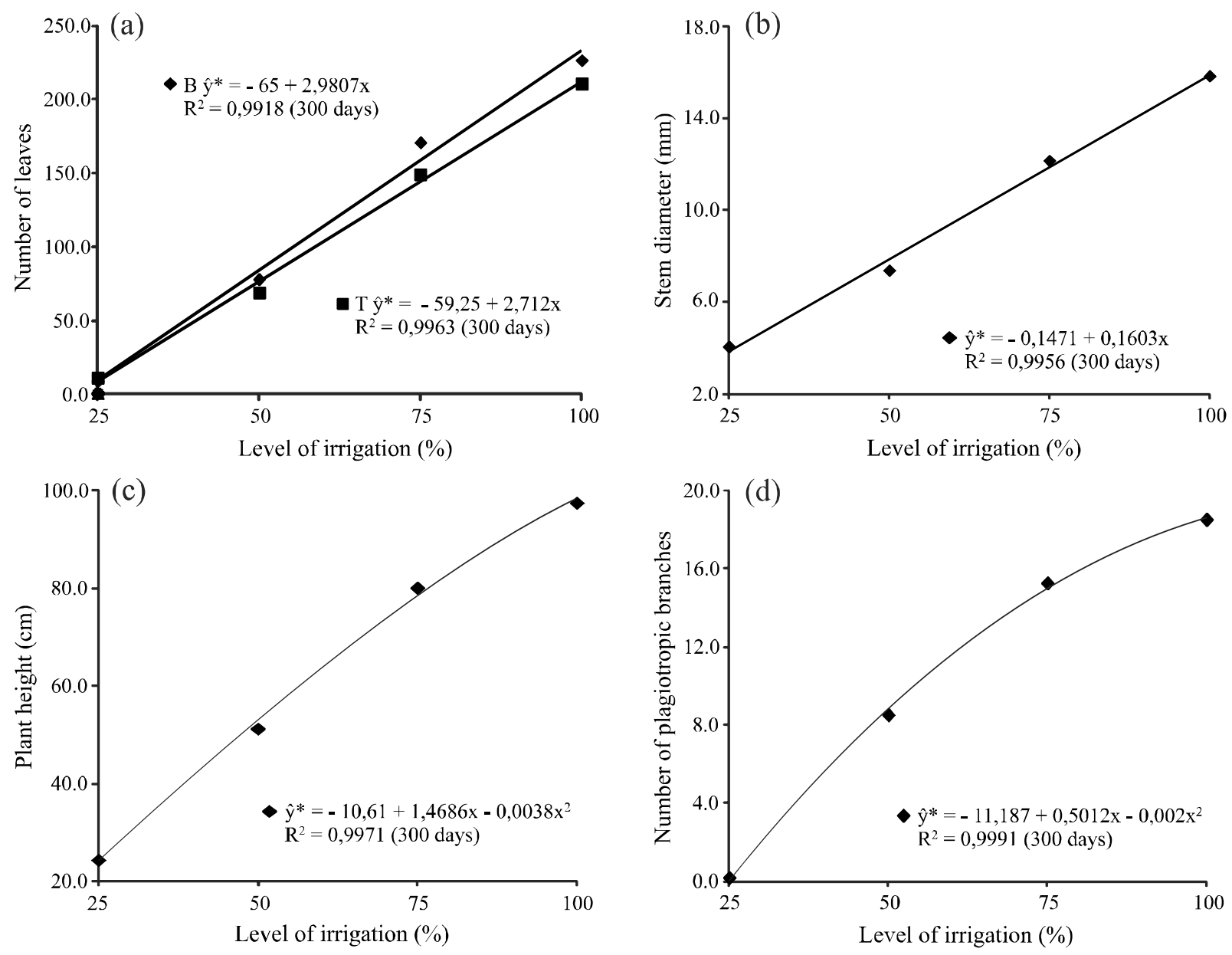

"Significant difference by F-test at 5\% probability within each period

Table 2 - Leaf area in $\mathrm{cm}^{2}$ (LA) at 240 and 300 days, and stem diameter in mm (SD) at 360 days, in plants of Arabica coffee cultivar Acaiá Cerrado MG-1474 in a clay soil

\begin{tabular}{lccc}
\hline \multicolumn{1}{c}{ Polymer } & LA 240 days & LA 300 days & SD 360 days \\
\hline No Gel (0) & $1700.55 \mathrm{~B}$ & $2557.42 \mathrm{~B}$ & $11.46 \mathrm{~B}$ \\
With Gel (G) & $1826.51 \mathrm{~A}$ & $2913.91 \mathrm{~A}$ & $12.17 \mathrm{~A}$ \\
\hline
\end{tabular}

*Diferent letters in a column indicate a significant difference by F-test at $5 \%$ probability

per plant, which may increase the number of buds, thereby influencing production.

At the end of the experiment (360 days), an effect was found from irrigation (I) on plant height $(\mathrm{PH})$, and leaf area (LA), with the highest levels of irrigation giving greater values for PH and LA (Figure $7 \mathrm{a}$ and $7 \mathrm{~b}$ ). Analysing the $\mathrm{PH}$, an increasing quadratic trend was noted for increasing levels of irrigation. The difference between the irrigation levels of $50 \%$ and $100 \%$ was $41.41 \mathrm{~cm}$, i.e. at the level of $50 \%$, plant height (Figure 7a) was 59\% lower when compared to the level of $100 \%$.

Analysing Figure 7b, it can be seen that there was a linear trend in the growth of LA for increases in irrigation level, with the largest growth, of $6,859 \mathrm{~cm}^{2}$, occurring at the level of $100 \%$. The gain in leaf area for each $25 \%$ level of irrigation was equal to $179.8 \mathrm{~cm}^{2}$. A larger leaf area can 
Figure 7 - Plant height (cm) (a) and leaf area $\left(\mathrm{cm}^{2}\right)(b)$ at 360 days after planting, in the Acaiá Cerrado MG-1474 coffee cultivar, for level of irrigation
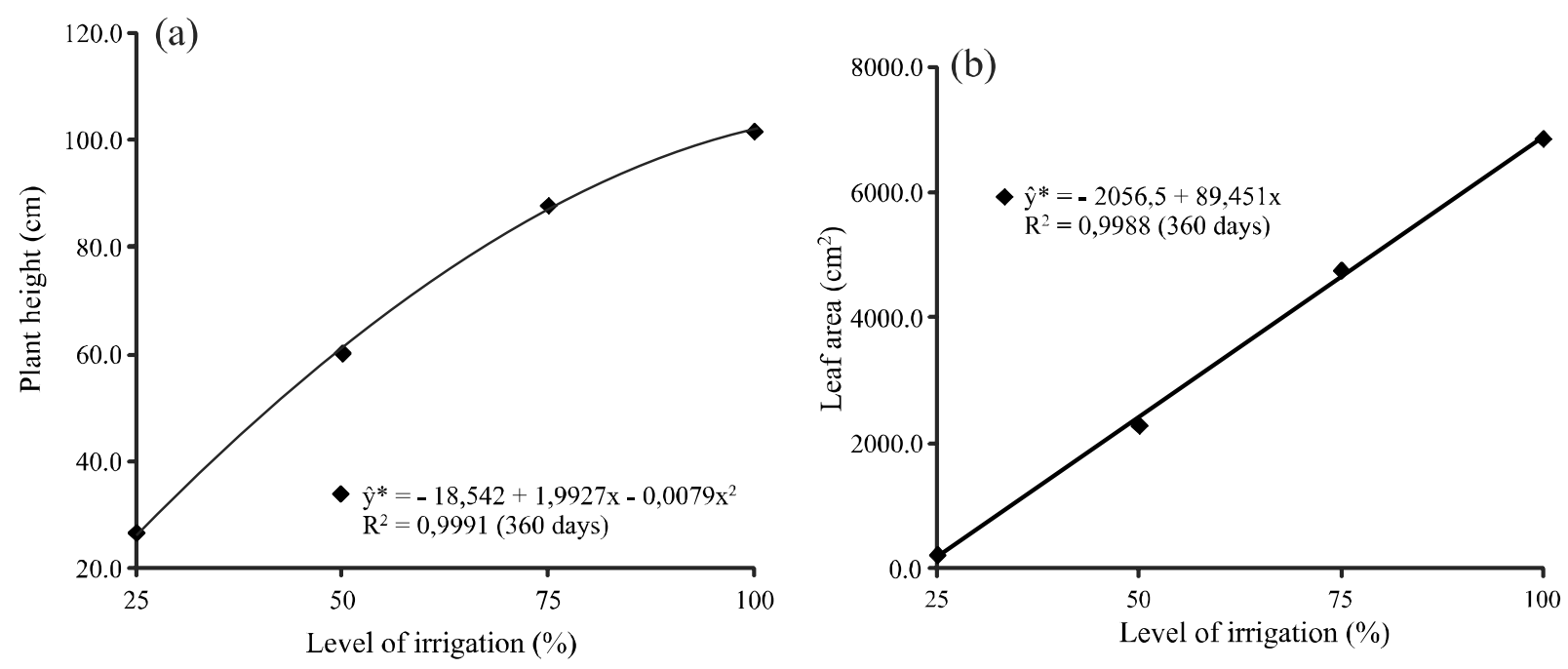

"Significant difference by F-test at $5 \%$ probability within each period

Table 3 - Number of leaves (NL) at 60, 240 and 360 days, and number of plagiotropic branches (NPB) at 120 and 360 days, in plants of Arabica coffee cultivar Acaiá Cerrado MG-1474 in a clay soil

\begin{tabular}{lccccc}
\hline Seedling type & NL 60 days & NL 240 days & NL 360 days & NPB 120 days & NPB 360 days \\
\hline Tube (T) & $13 \mathrm{~B}$ & $62 \mathrm{~B}$ & $149 \mathrm{~B}$ & $2 \mathrm{~B}$ & $11 \mathrm{~B}$ \\
Bag (B) & $14 \mathrm{~A}$ & $69 \mathrm{~A}$ & $165 \mathrm{~A}$ & $3 \mathrm{~A}$ & $13 \mathrm{~A}$ \\
\hline
\end{tabular}

* Diferent letters in a column indicate a significant difference by $\mathrm{F}$-test at $5 \%$ probability

promote greater productivity; Livramento (2010) points out that $20 \mathrm{~cm}^{2}$ of leaf area is necessary for the formation of each coffee fruit.

At 360 days, the coffee seedlings that received the application of water-retaining polymer (G) displayed a greater SD; the value found for SD was $12.2 \mathrm{~mm}$, while the seedlings that did not receive the product had an SD of only $11.5 \mathrm{~mm}$ (Table 2). Pieve et al. (2013), evaluating the dose and type of application of water-retaining polymer in coffee plants at 476 days after planting, found that applying the water-retaining polymer to the planting hole favoured a larger stem diameter in the plants, $15.4 \%$ greater than when the polymer was not used. A larger stem diameter is desirable, since according to Livramento (2010), plants that have more vigorous stems can accumulate greater quantities of carbohydrates, with a consequent increase in vegetative growth and reproductive development.

For the same period (360 days), the seedlings produced in bags and tubes showed differences in the number of leaves and plagiotropic branches. Seedlings from the bags had 165 leaves and 13 plagiotropic branches, while seedlings from the tubes had 149 leaves and 11 plagiotropic branches (Table 3). A greater number of plagiotropic branches were also found in the field by Nasser, Gallo and Fonseca (2011) when evaluating the development of coffee plants at 325 days after planting.

\section{CONCLUSION}

1. Irrigation promotes greater growth in the coffee plant, which benefits from the use of water-retaining polymer when the crop is planted;

2. Seedlings produced in bags display greater growth than seedlings in tubes when planting the coffee crop.

\section{ACKNOWLEDGEMENT}

The authors wish to thank Fapemig for the scholarships. 
The authors further wish to thank UFLA (Sector for Coffee Production) for their support in conducting the experiment.

This work was carried out with the support of $\mathrm{CNPq}$, the National Council for Scientific and Technological Development, Brazil.

\section{REFERENCES}

ALMEIDA, L. S. de et al. Crescimento de mudas de Jacaranda puberula Cham. em viveiro, submetidas a diferentes níveis de luminosidade. Ciência Florestal, v. 15, n. 3, p. 323-329, 2005.

ALVES, M. E. B. et al. Crescimento do cafeeiro sob diferentes lâminas de irrigação e fertirrigação. Revista Brasileira de Engenharia Agrícola e Ambiental, v. 4, n. 2, p. 219-225, 2000.

ATKINSON, C. J. et al. Drought tolerance of apple rootstocks: production and partitioning of dry matter. Plant and Soil, v. 206, p. 223-235, 1999.

AZEVEDO, T. L. F. et al. Níveis de polímero superabsorvente, frequências de irrigação e crescimento de mudas de café. Acta Scientiarum, v. 24, n. 5, p. 1239-1243, 2002.

CARVALHO, A. D. et al. Correlação entre crescimento e produtividade de cultivares de café em diferentes regiões de Minas Gerais, Brasil. Pesquisa Agropecuária Brasileira, v. 45, n. 3, p. 269-275, mar. 2010.

CARVAlHO, G.; ADÃO, W. A arte de lidar com café. Estado de Minas, Belo Horizonte, 10 fev. 2014. Disponível em: $<$ http://www.redepeabirus.com.br/redes/form/post?topico id $=50597>$. Acesso em: 18 fev. 2014

COMPANHIA NACIONAL DE ABASTECIMENTO. Acompanhamento da safra brasileira: café: safra 2014: primeiro levantamento. janeiro/2014. Disponível em http://www.conab.gov. br/OlalaCMS/uploads/arquivos/14_01_17_09_29_46_boletim_ cafe_-_original_normalizado.pdf. Acesso em 25 mar. 2014.

DANTAS, A. A. A.; CARVAlho, L. G.; FERREIRA, E. Classificação e tendências climáticas em Lavras, MG. Ciência e Agrotecnologia, v. 31, n. 6, p. 1862-1866, 2007.

FAQUIN, V.; VALE, F. R.; FURTINI NETO, A. E. Cultivo de plantas em ambiente controlado: solução nutritiva, hidroponia e em vasos com solo. Lavras: UFLA, 2008. 18 p.

FAVARIN, J. L. et al. Equações para a estimativa do índice de área foliar do cafeeiro. Pesquisa Agropecuária Brasileira, v. 37, n. 6 , p. $769-773,2002$.
FERREIRA, D. F. Sisvar: a computer statistical analysis system. Ciência e Agrotecnologia, v. 35, n. 6, p. 1039-1042, 2011.

LIVRAMENTO, D. E. do. Morfologia e fisiologia do cafeeiro. In: REIS, P. R.; CUNHA, R. L. (Ed.). Café arábica: do plantio à colheita. Lavras: EPAMIG, 2010. p. 87-161.

MARTINS, C. C. et al. Crescimento inicial do café Conilon (Coffea canephora Pierre ex Froehner) sob diferentes lâminas de irrigação. Engenharia na Agricultura, v. 14, n. 3, p. 193-201, 2006.

NASSER, M. D.; GALlO, P. B.; FONSECA, R. da. Desenvolvimento pós-plantio de Coffea arabica L. em sacola plástica convencional, tubete e TNT. In: SIMPÓSIO DE PESQUISA DOS CAFÉS DO BRASIL, 7., 2011, Araxá. Anais... Brasília: Embrapa Café, 2011. 2 CD-ROM.

OLIVEIRA, R. A. et al. Influência de um polímero hidroabsorvente sobre a retenção de água no solo. Revista Brasileira de Engenharia Agrícola e Ambiental, v. 8, n. 1, p. 160-163, 2004.

PIEVE, L. M. et al. Uso de polímero hidro retentor na implantação de lavouras cafeeiras. Coffee Science, v. 8, n. 3, p. 314-323, 2013.

SANTANA, M. S.; OLIVEIRA, C. A. S.; QUADROS, M. Crescimento de duas cultivares de cafeeiro adensado influenciado por níveis de irrigação localizada. Engenharia Agrícola, v. 24, n. 3, p. 644-653, 2004.

SANTOS, H. G. dos. Sistema brasileiro de classificação de solos. 3. ed. Brasília: EMBRAPA, 2013. 353 p.

SCALCO, M. S. et al. Influência de diferentes critérios de irrigação e densidades de plantio sobre o crescimento inicial do cafeeiro. In: SIMPÓSIO BRASILEIRO DE PESQUISA EM CAFEICULTURA IRRIGADA, 5., 2002, Araguari. Anais... Uberlândia: UFU, 2002. p. 150-155.

TOHIDI-MOGHADAM, H. R. et al. Response of six oilseed rape genotypes to water stress and hydrogel application. Pesquisa Agropecuária Tropical, v. 39, n. 3, p. 243-250, 2009.

VALE, G. F.; CARVALHO, S. P.; PAIVA, L. C. Avaliação da eficiência de polímero hidro retentor no desenvolvimento do cafeeiro em pós-plantio. Coffee Science, v. 1, n. 1, p. 7-13, 2006.

VALLONE, H. S. et al. Diferentes recipientes e substratos na produção de mudas de cafeeiros. Ciência e Agrotecnologia, v. 34 , n. 1, p. 55-60, 2010.

ZONTA, J. H. et al. Influência de diferentes turnos de rega e doses de hidroabsorvente no desenvolvimento inicial da cultura do café conillon (Coffea canephora Pierre). Idesia, v. 27, n. 3 , p. $29-34,2009$. 